\title{
METODY OCHRONY MOSTÓW RUROCIĄGOWYCH PRZED SKUTKAMI UDERZENIA HYDRAULICZNEGO
}

\begin{abstract}
W artykule omówiono wybrane metody zabezpieczenia mostów rurociągowych przed skutkami uderzenia hydraulicznego. Wskazano na przyczyny i możliwe zniszczenia spowodowane uderzeniem hydraulicznym. Zamieszczono przegląd aktualnie stosowanych metod ochrony przed uderzeniem hydraulicznym, wykonano porównanie efektywności wybranych systemów ochrony przed uderzeniem hydraulicznym. Zwrócono uwagę na fakt, że częstości drgań własnych mostów rurociągowych mogą odpowiadać częstościom zmian ciśnienia fali uderzenia hydraulicznego i być powodem rezonansu.
\end{abstract}

Słowa kluczowe: mosty rurociągowe, uderzenie hydrauliczne, ochrona przed uderzeniem hydraulicznym, częstości drgań własnych mostów rurociągowych

\section{Wprowadzenie}

Niskie koszty eksploatacji powodują, że transport rurociągowy jest jedną z metod, najczęściej wykorzystywanych do przesyłu na duże odległości cieczy: wody, ścieków, ropy naftowej i jej produktów czy też zawiesin np. produktów odpadowych kopalni węgla, miedzi. Istotnym elementem drogi transportu są przeprawy mostowe, którymi mogą być rurociągi zamocowane bezpośrednio do istniejącego mostu, konstrukcje samonośne, rurociągi zamocowane do konstrukcji wsporczej lub konstrukcje wiszące. Przykłady przedstawiono na rys. 1.

W porównaniu do mostów drogowych i kolejowych mosty rurociągowe są konstrukcjami, których własności dynamiczne są stosunkowo słabo zbadane. Awaria rurociągowych systemów transportowych może spowodować poważne skutki: odcięcie zaopatrzenia w wodę dużych skupisk ludności czy też ośrodków przemysłowych, a w przypadku transportu materiałów ropopochodnych zanieczyszczenia środowiska naturalnego, należy więc przewidzieć możliwe sytuacje i mechanizmy prowadzące do ich zniszczenia. W pracy zwrócono uwagę na

\footnotetext{
1 Autor do korespondencji / corresponding author: Szymon Imiełowski, Politechnika Warszawska, Wydział Instalacji Budowlanych, Hydrotechniki i Inżynierii Środowiska, Nowowiejska 20, 00-653 Warszawa, szymon.imielowski@is.pw.edu.pl

2 Bartosz Śniegocki, Politechnika Warszawska, Wydział Instalacji Budowlanych, Hydrotechniki i Inżynierii Środowiska, Nowowiejska 20, 00-653 Warszawa, bartosz.sniegocki@is.pw.edu.pl
} 
możliwość awarii wywołanej uderzeniem hydraulicznym. Artykuł stanowi podsumowanie i uzupełnienie zagadnień zawartych w pracy [2].
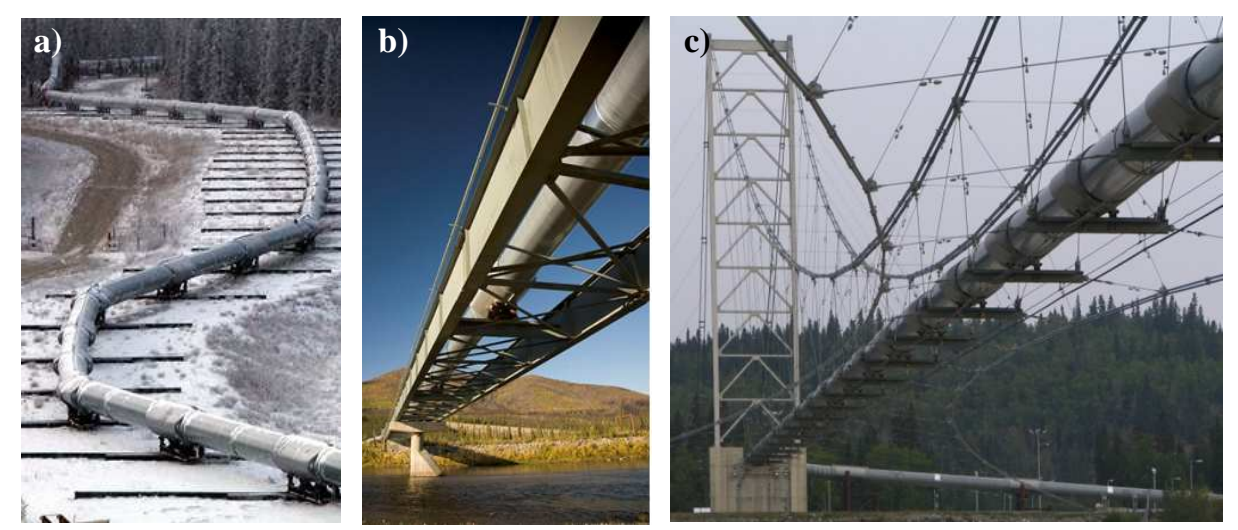

Rys. 1. Przykłady konstrukcji estakady (a) i mostów rurociągowych (b), (c) na trasie rurociągu Trans-Alaska Pipeline [1]

Fig. 1. Examples of above ground (a) and pipeline bridges (b), (c) on Trans-Alaska Pipeline [1]

\section{Zjawisko uderzenia hydraulicznego}

Uderzenie hydrauliczne polega na gwałtownej zmianie ciśnienia, w przewodzie transportujących ciecz, wskutek nagłego otwarcia/zamknięcia zaworu, uruchomienia lub zatrzymania pomp, awarii zaworów bezpieczeństwa [3, 4].

W wyniku uderzenia hydraulicznego energia kinetyczna cieczy ulega zamianie na energię ściśliwości cieczy i sprężystości ścianek przewodu. Powstaje fala ciśnienia charakteryzująca się dużymi zmianami ciśnienia [3], które stanowi dodatkowe obciążenie rurociągu. W poziomym przewodzie DN $200 \mathrm{~mm}$ i długości $500 \mathrm{~m}$ transportującym wodę z prędkością $3 \mathrm{~m} / \mathrm{s} \mathrm{w}$ temperaturze otoczenia, w wyniku szybkiego zamknięcia zaworów ciśnienie może wzrosnąć od 6 bar przy przepływie stacjonarnym do 40 bar w warunkach uderzenia hydraulicz-
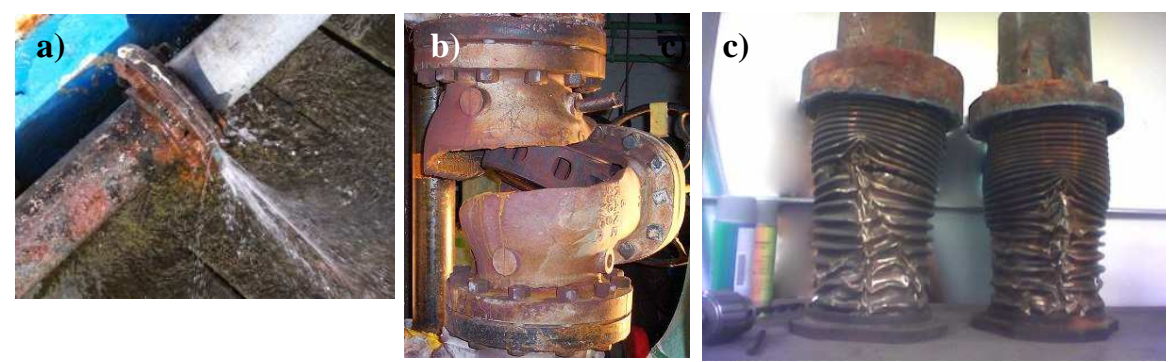

Rys. 2. Skutki uderzenia hydraulicznego: a) uszkodzenie uszczelki [6], b) zniszczenie obudowy zaworu [7] c) wgniecenia powierzchni połączeń dylatacyjnych [8]

Fig. 2. Effects of a water hammer: a) failure of a seal [6], b) destruction of the valve casing [7], c) collapsing of expansion joints [8] 
nego [5]. Tak duże obciążenie może być powodem uszkodzeń przewodu, połączeń pomiędzy jego elementami, pomp, zaworów, zainstalowanej aparatury pomiarowej, a także niekorzystnych wibracji przewodu i hałasu. Przykłady zniszczeń rurociągu wywołanych uderzeniem hydraulicznym przedstawiono na rys. 2. W wyniku uderzenia hydraulicznego ciśnienie cieczy w przewodzie może spaść do wartości mniejszej niż wartość ciśnienia atmosferycznego i doprowadzić do kawitacji lub wgnieceń powierzchni przewodu (rys. 2c).

\section{O możliwości wystąpienia rezonansu mostu rurociągowego w warunkach uderzenia hydraulicznego}

W sytuacji gdy częstości drgań fali uderzenia hydraulicznego zawiera się w zakresie drgań własnych mostu rurociągowego, może dojść do znacznego zwiększenia amplitudy drgań mostu.

W pracy [9] wyznaczono częstości drgań i formy własne mostu rurociągowego Nakagawa Water-pipe Bridge w Japonii. Do transportu wody przewidziano 2 przewody o średnicy $900 \mathrm{~mm}$, oparte na pięcio-przęsłowej konstrukcji kratowej, której trzy wewnętrzne przęsła są zawieszone na cięgnach. Całkowita długość mostu wznosi $492 \mathrm{~m}$, długość głównego przęsła $145 \mathrm{~m}$. Na podstawie pomiarów oraz wyników obliczeń modelu MES, wyznaczono pierwsze 15 częstości, które są zawarte w zakresie $0,54 \div 1,91 \mathrm{~Hz}$. Przedstawione przez autorów dane umożliwiają wyznaczenie przybliżonych wartości częstotliwości drgań fali uderzenia hydraulicznego. Most rurociągowy transportuje wodę, dla której prędkość rozprzestrzeniania się fali wynosi $c=1452 \mathrm{~m} / \mathrm{s}$. Czas powrotu fali odbitej wynosi więc $T_{R}=2 \mathrm{~L} / \mathrm{c}=2 \cdot 492 / 1425=0,69 \mathrm{~s}$, okres drgań $T=2 T_{R}=2 \cdot 0,69=1,38 \mathrm{~s}$, a częstotliwość $f=1 / T=1 / 1,38=0,721 / \mathrm{s}$. Whydraulice definiuje się czas powrotu fali odbitej $T_{R}=0,5 T$, gdzie $T$ jest okresem zmian ciśnienia wywołanego uderzeniem hydraulicznym. Częstotliwość drgań fali uderzenia hydraulicznego mieści się więc w zakresie spektrum częstości drgań własnych mostu, może wystąpić rezonans.

Szczególnie wrażliwe na obciążenia dynamiczne są rurociągowe mosty wiszące [10]. Niekorzystnym zjawiskiem występujących podczas eksploatacji tych mostów jest możliwość zmian charakterystyk dynamicznych mostu. Zmiana częstości drgań własnych może być spowodowana zmianą naciągu cięgien lub oblodzeniem cięgien. Oblodzenie zwykle wpływa niekorzystnie na eksploatację, powodując drgania galopujące. Autor pracy [11], zwrócił uwagę, że oblodzenie może mieć również wpływ korzystny. Podwójny wzrost masy rurociągu spowodowany oblodzeniem może wzmocnić jego odporność na obciążenie wiatrem o $160 \%$.

Szczegółowa analiza charakterystyk dynamicznych mostów rurociągowych jest niezbędna w przypadku mostów budowanych na terenach zagrożonych trzęsieniami ziemi, gdzie charakterystyka częstotliwościowa obciążenia jest bardzo zróżnicowana. Trzęsienie ziemi w 2011 w Japonii było powodem awarii kilku mostów, m.in. mostu Nagakawa Water-pipe Bridge [9]. 
W przypadku rurociągu podwieszonego do istniejącego mostu, istotny jest sposób zamocowania przewodu do mostu, który ma wpływ na częstość drgań uderzenia hydraulicznego. Drgania mostu, poprzez podpory, są przenoszone na rurociąg stanowiąc dodatkowe źródło wzbudzenia. Tę tematykę podejmują autorzy prac [12-14].

Powyższe uwagi wskazują, że podczas eksploatacji, częstości drgań własnych mostu rurociągowego jak i charakterystyki samego rurociągu, mogą ulegać zmianie. Urządzenia zabezpieczające przed skutkami uderzenia hydraulicznego powinny więc skutecznie przeciwdziałać drganiom z określoną, jedną częstością jak również efektywnie działać w pewnym przedziale częstości niebezpiecznych z punktu widzenia możliwości powstania rezonansu. Wskazana jest również możliwość dostosowanie częstości drgań urządzenia podczas eksploatacji obiektu do aktualnej wartości parametrów mostu.

\section{Ochrona przewodu przed skutkami uderzenia hydraulicznego}

Metody zabezpieczenia rurociągu przed skutkami uderzenia hydraulicznego można podzielić na dwie grupy: metody polegające na niedopuszczeniu do powstania fali uderzenia hydraulicznego i metody łagodzenia skutków uderzenia. Metody omówiono w pracach [3-5], [15-20] i zebrano w [2].

Do pierwszej grupy metod należy wymienić prawidłową eksploatację urządzeń transportu cieczy [3]. Stosowanie odpowiednio długiego czasu zamykania/otwierania, napowietrzanie strumienia płynącej cieczy zwiększające jej ściśliwość, spowolnienie napełniania sieci poprzez użycie pomp o dużej bezwładności wirnika, zastosowanie falowników zmniejszających obroty, powoduje znaczące ograniczenie wartości przyrostu ciśnienia.

W przypadku uderzenia, które może pojawić się w sposób nieprzewidziany, np. awaria pompy, stosuje się montowane do przewodu dodatkowe zewnętrzne urządzenia zabezpieczające. Mogą to być zawory o regulowanej prędkości zamykania, w których spowolnienie ruchu tłoka następuje wskutek wtłaczania gazu o regulowanym ciśnieniu (rys. 3d) [18], lepko-sprężyste tłumiki zamocowanego do klapy (rys. 3e) [19-20], układy hamulcowe, w których siła nacisku klocków zależy od ciśnienia cieczy w przewodzie, w warunkach uderzenia hydraulicznego (rys. 3f) [5]. Zagadnienia wpływu charakterystyki zamykania zaworu na przebieg zjawiska uderzenia hydraulicznego omówiono w [17].

Do metod polegających na łagodzeniu skutków uderzenia hydraulicznego należy stosowanie zaworów bezpieczeństwa [3]: wysokociśnieniowych otwieranych bezpośrednio naporem cieczy (rys. 3a) lub niskociśnieniowych, otwieranych za pomocą układu dźwigniowego, (rys. 3b). Po otwarciu zaworu ciecz wypływa na zewnątrz lub do zbiornika wyrównawczego. 
a)

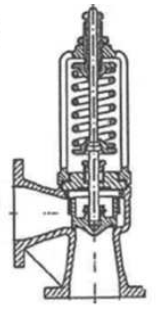

b)

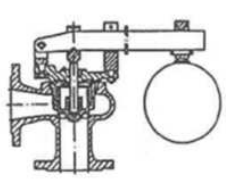

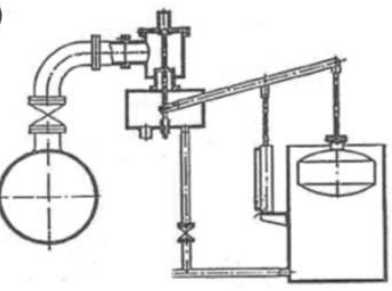

c)

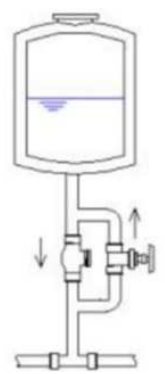

d)

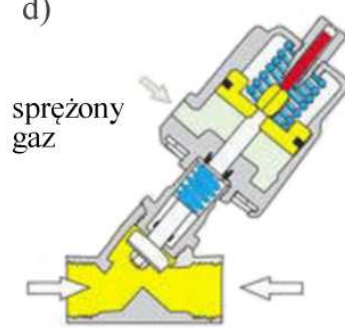

e)

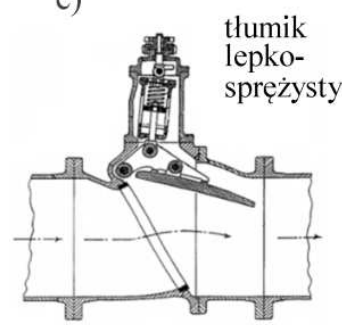

f)

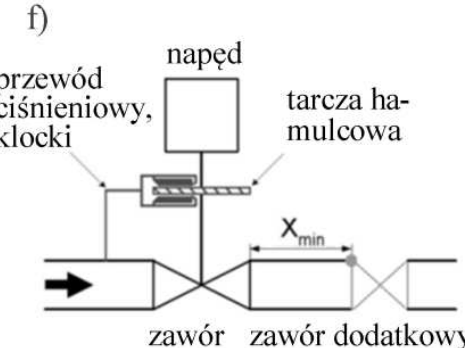

g)

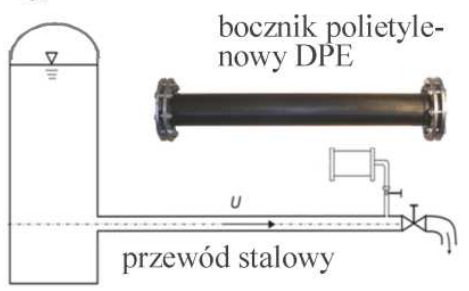

Rys. 3. Urządzenia zabezpieczające przed skutkami uderzenia hydraulicznego: a) zawory bezpieczeństwa wysokociśnieniowe, b) zawór bezpieczeństwa niskociśnieniowy, c) zbiornik wodno-powietrzny, d) zawór zwrotny sprężysty z poduszką gazową opóźniająca prędkość zamykania, e) zawór z lepkosprężystym regulatorem prędkości zamykania klapy, f) zawór z mechanizmem regulacji prędkości zamykania sterowanym ciśnieniem cieczy, g) instalacja z bocznikiem polietylenowym; na podstawie [3, 5, 15, 16, 18, 19]

Fig. 3. Devices protecting against the water hammer effects: a) high-pressure safety valve, b) a low-pressure safety valve, c) a surge tank, d) a spring check valve with an air cushion that slows down the velocity of closing, e) a valve with a viscoelastic regulator of the flap closing velocity, f) a valve with regulated closing velocity controlled by fluid pressure, g) an installation with a polyethylene bypass; based on $[3,5,15,16,18,19]$

Stosowane są również montowane do rurociągu zewnętrzne urządzenia zabezpieczające, w których następuje rozpraszanie przyrostu energii cieczy wywołanego uderzeniem hydraulicznym. Są nimi: zbiorniki wodno-gazowe (rys. 3c) [3], które przejmują część cieczy i w ten sposób przeciwdziałają nadmiernemu przyrostowi ciśnienia wywołanemu uderzeniem hydraulicznym; wbudowane segmenty rur i dodatkowe boczniki wykonane z materiału o podatności większej 
od podatności materiału rurociągu, np. z polietylenu (rys. 3g) [15-16]. W tym przypadku efekt tłumienia jest spowodowany różnicą pomiędzy częstością drgań własnych materiału, z którego wykonano urządzenie tłumiące i częstością drgań fali uderzenie hydraulicznego. W przypadku boczników wykorzystywany jest dodatkowo efekt gromadzenia objętości cieczy w boczniku. Polietylen jest materiałem wrażliwym na prędkość odkształcenia, w warunkach zwiększonego ciśnienia wywołanego uderzeniem hydraulicznym i obserwuje się wzrost modułu Younga. Badania sztywności materiałów stosowanych do wyrobu przewodów hydraulicznych były tematem prac [21, 22].

Tłumienie nadmiernych drgań rurociągu zapewniają również elastyczne podpory lub dynamiczne eliminatory drgań. Prawidłowo zaprojektowane podpory są istotne zwłaszcza w przypadku przewodów zamocowanych do konstrukcji wsporczej lub do istniejących mostów (rys. 1a, b).
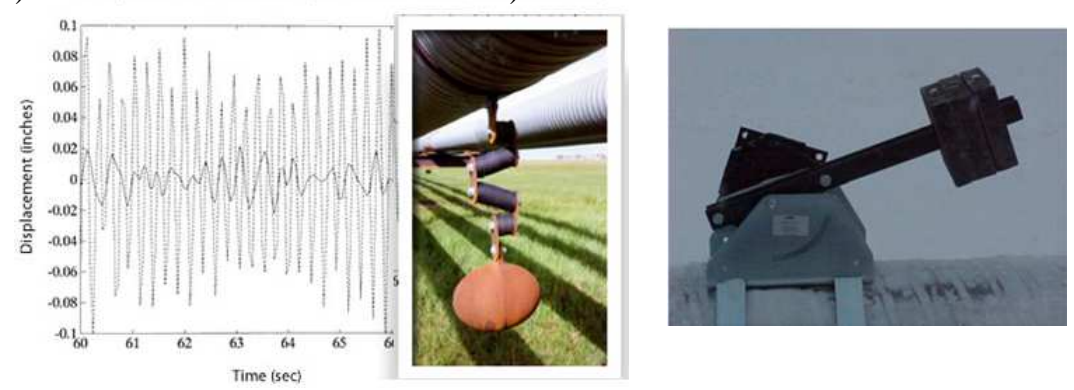

Rys. 4. Zastosowanie tłumików dynamicznych, Alaska, USA: a) eliminator dynamiczny oraz wykres drgań bez eliminatora i z zamocowanym eliminatorem, b) tłumik uderzeniowy; na podstawie $[23,24]$

Fig. 4. Application of dynamic dampers, Alaska, USA: a) the dynamic vibration absorber and diagram of a pipeline vibration with and without absorber, b) a hammer damper; based on [23, 24]

Autorzy pracy [12-14] stwierdzili, że zastosowanie odpowiednio zaprojektowanych elastycznych podpór może zmniejszyć wartości naprężeń wywołanych obciążeniem dynamicznym nawet o $40 \%$.

Dynamiczne eliminatory drgań zastosowano $\mathrm{np}$. w rurociągach budowanych na Alasce [23, 24]. Konieczność zapewnienia swobodnego przejścia zwierząt i niekorzystne warunki gruntowe spowodowały, że rurociąg poprowadzono na podporach w postaci estakady (rys. 1a). Do redukcji drgań wykorzystano eliminatory dynamiczne (rys. 4a) i thumiki uderzeniowe (rys. 4b).

Należy wspomnieć, że wszystkie omawiane powyżej rozwiązania urządzeń tłumiących są układami pasywnymi, nie wymagają dodatkowych źródeł energii. 


\section{Porównanie efektywności wybranych metod thumienia drgań wywołanych uderzeniem hydraulicznym}

Na rys. 5 zestawiono wykresy zmian ciśnienia wybranych urządzeń zabezpieczających przed skutkami uderzenia hydraulicznego, przedstawionych na rys. 3e i $3 \mathrm{~g}$. Analiza wykresów wskazuje na wysoką efektywność urządzenia na rys. 3e, następuje wygaszenie już pierwszej fali uderzenia hydraulicznego.
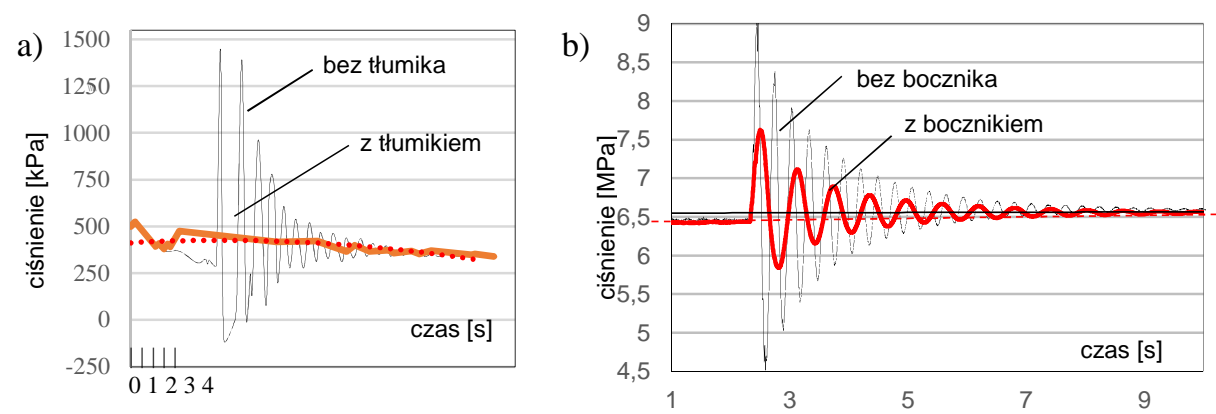

Rys. 5. Porównanie efektywności tłumików uderzenia hydraulicznego: a) zawór klapowy z regulacją prędkości zamykania tłumkiem lepko-sprężystym (rys. 3e), b) bocznik polietylenowy (przewód stalowy, długość 40 m, średnica 2", wydatek 50 l/s (rys. 3g); na podstawie [15, 16, 19, 20]

Fig. 5. Comparison of the efficiency of water hammer dampers: a) flap valve with a visco-elastic regulator of the flap closing velocity (Fig. 3e), b) polyethylene bypass (steel conduit, length $40 \mathrm{~m}$, diameter 2", expenditure of $50 \mathrm{l} / \mathrm{s}$ (Fig. 3g); based on $[15,16,19,20]$

Polietylenowe boczniki (rys. 3g), wykazują również wysoką efektywność tłumienia, ich zaletą jest niewielka zmiana wartości ciśnienia średniego i niewielki spadek ciśnienia. Wadą są duże rozmiary urządzenia.

Wybór urządzenia jest związany ze specyfiką każdego obiektu mostowego: średnicą przewodu, dopuszczalnym ciśnieniem czy rodzajem transportowanego medium. W przypadku zaworów mogą wystąpić ograniczenia np. średnicy czy maksymalnego ciśnienia. Takich ograniczeń praktycznie nie ma rozwiązanie polietylenowego bocznika. Klasyfikację umożliwiającą ocenę efektywności urządzeń tłumiących, przyjmując kryteria: zmniejszenia amplitudy fali ciśnienia wywołanej uderzeniem, zmianę średniej wartości ciśnienia oraz najmniejszą wartość ciśnienia wprowadzono w pracy [2].

\section{Podsumowanie}

Wśród obciążeń wyjątkowych, które mogą stanowić obciążenie instalacji mostów rurociągowych uderzenie hydrauliczne może pojawić się podczas eksploatacji nawet w prawidłowo użytkowanej instalacji, np. wskutek awarii pomp czy wyłączenia energii elektrycznej. W pracy zawarto przegląd aktualnie stoso- 
wanych metod ochrony przed uderzeniem hydraulicznym. Wykonano porównanie efektywności dwóch wybranych systemów ochrony przed uderzeniem hydraulicznym. Podano przykłady wykorzystania eliminatorów drgań i elastycznych podpór do eliminacji drgań mostów.

Mosty rurociągowe, zwłaszcza te o konstrukcji wiszącej są szczególnie wrażliwe na obciążenia dynamiczne. Zmiany naciągu cięgien, oblodzenie czy zmian własności materiału, mogą doprowadzić do zmian częstości drgań mostu już podczas eksploatacji i zbliżyć się do częstości rezonansowych, odpowiadających częstościom drgań uderzenia hydraulicznego. Projekt mostu rurociągowego powinien uwzględniać zmiany sztywności występujące podczas eksploatacji.

\section{Literatura}

[1] https://en.wikipedia.org/wiki/Trans-Alaska_Pipeline_System (dostęp: 10.04.2017 r.).

[2] Imiełowski Sz., Śniegocki B.: Zabezpieczenie mostów rurociągowych przed drganiami wywołanymi uderzeniem hydraulicznym, Roads and Bridges-Drogi i Mosty, 16 (2017) 65-79.

[3] Mitosek M.: Mechanika płynów w inżynierii i ochronie środowiska, OWPW, Warszawa 2007.

[4] Allaf K.: Ważne kryteria do obniżenia kosztu systemów ochrony długich linii transportu wody. Napędy i sterowanie, 6, 2015, 80-85.

[5] Dudlik A., Handajani Schönfeld S.B., Schlüter S., Fahlenkamp H., Prasser H.M.: Prevention of Water Hammer and Cavitational Hammer in Pipeline System, Chemical Engineering and Technology, 25, 9, 2002, 888-890.

[6] https://sites.google.com/site/metropolitanforensics/water-damage-claims-due-tofreeze-up-and-burst-water-pipes (dostęp: 10.04.2017 r.).

[7] http://www.kirsner.org/pages/forensicResAlt.html (dostęp: 10.04.2017 r.).

[8] https://en.wikipedia.org/wiki/Water_hammer (dostęp: 10.04.2017 r.).

[9] Kaminaka R., Kuwata Y.: Damage Mechanism of the Nakagawa Water-pipe Bridge during the 2011 off The Pacific Coast of Tohoku Earthquake,15 WCEE, Lisboa 2012.

[10] Prokopowicz D., Bryja D.: Wiszące mosty rurociągowe - historia i przegląd stosowanych rozwiązań konstrukcyjnych. Przegląd budowlany, 9, 2015, 30-37.

[11] Scott R.: In the wake of Tacoma: Suspensions bridges and the quest for Aerodynamics Stability, ASCE, 2001.

[12] Trebuňa F., Bocko J.,Delyová I., Sivák P.: Application of Computational Methods and Methods of Experimental Stress Analysis for Determination of Lifespan of Pipe Yards. Acta Mechanica Slovaca, 15, 4, 2011, 52-57.

[13] Trebuňa F., Bocko J.,Delyová I., Sivák P.: Quantification of Force Effects in Dynamically Loaded Pipe Systems. American Journal of Mechanical Engineering, Vol. 1, No. 7, 2013, 398-402.

[14] Sivak P., Delyova I., Hroncova D.: ESA as a Significant Tool for Intensification of Structural Elements of Pipe Systems. American Journal of Mechanical Engineering, Vol. 3, No. 6, 2015, 261-266. 
[15] Mitosek M., Roszkowski A:.Empirical Study of Water Hammer in Plastics Pipes, Plastics Pipes X, Proceedings of the „Plastics Pipeline Systems for the Millenium” Conference, The Institute of Materials, London/Goeteborg, 1998, 233-248.

[16] Mitosek M., Kodura A., Kołakowska A., Wrzosek K.: Analiza doświadczalna zdolności tłumienia fali ciśnienia wywołanej uderzeniem hydraulicznym w przewodzie stalowym poprzez zastosowanie rurowego tłumika HDPE, Prace statut. ZBWiH PW, 2013.

[17] Kodura A.: An Analysis of the Impact of Valve Closure Time on the Course of Water Hammer, Archives of Hydro-Engineering and Environmental Mechanics, Vol. 63, No.1, 2016, 35-45.

[18] www.stcvalve.com/Air_Actuated_valve_specification-2KS.htm, 10.02.2017.

[19] www.aquadevice.com/english/04valve_slsn1.htm, 10.02.2017.

[20] US Patent 005746246A, Water hammer preventing check valve, Yokota et all., 1998.

[21] Imiełowski Sz., Kodura A., Glinicka A., Ajdukiewicz C.: Experimental Study on Mechanical Properties of Polyethylene HDPE in Conditions of Hydraulic Impact Simulation, Solid State Phenomena, Vol. 240, 2016, 149-154.

[22] Imiełowski Sz., Kodura A., Glinicka A., Ajdukiewicz C.: Influence of Hydraulic Impact on Mechanical Properties of Polyethylene MDPE and PCV Pipes, Engineering Transactions, 2017 /in print/.

[23] Norris M.A. , Keith R., Ptak B., Zamora A., Hart D.J.: Implementation of Tuned Vibration Absorbers for Above Ground Pipeline Vibration Control, Proceedings of the IPC 2000 ASME International Pipeline Conference, October 1-5, 2000, Calgary, Alberta, Canada, 1-5.

[24] Collins M. G., Hart J.D.: The impact of High Frequency Wind - Induced Vibration on Arctic Pipeline Systems, 1992.

\section{METHODS OF THE PIPELINE BRIDGES PROTECTION AGAINST THE EFFECTS OF WATER HAMMER}

This article discusses selected methods of protecting pipeline bridges against the impact of water hammer. The reasons of this phenomenon and possible failure caused by them are discussed in this article. An overview of the currently used protection methods against water hammer are shown. Effectiveness of selected systems of protection against water hammer is discussed in details. It is underlined that natural frequencies of the pipeline bridge can coincide with frequency of the fluid pressure wave caused by water hammer and can bring about resonance vibration.

Keywords: pipeline bridges, water hammer, protection from water hammer, pipelines bridges eigenfrequencies 